\title{
Anna Kruglova
}

\section{Petra Rethmann. Russia: Anthropological Insights. North York, ON: University of Toronto Press, 2018. 136 pp. ISBN: 978-1-4426-3657-6.}

Anna Kruglova, National Research University - Higher School of Economics. Address for correspondence: Miasnitskaia ul., 11, Rm. 530, Moscow, 101000, Russia. akruglova@hse.ru.

This book is a long-awaited introductory text covering Russian history, politics, and culture through a distinctively anthropological lens. It is intended for undergraduates with no prior knowledge of the country and focuses on the public and political life of contemporary Russian society. Deliberately short, the text is divided into seven chapters. The chapters are prefaced by a six-page introduction and followed by a glossary, bibliography, and index. Each chapter follows a no-nonsense scheme, beginning with a "brief history" overview of the respective theme, which is then developed further in a general discussion and more detailed description of an "ethnographic close-up." The introduction contains an encyclopedia-style overview of anthropological methods, the discipline's aversion to essentialism and stereotype, and a discussion of "culture" as it is used by anthropologists who study Russia. It focuses on the importance of Enlightenment ideals and the role of the intelligentsia in Russian history and culture. Chapter 2, "Tournaments of Change: Socialism, Awakening, Transition, Post-Socialism," is historiographical and conforms to its title precisely. It is a sequential description of socialism and its "instrumental rationality"; the "awakening" of perestroika and glasnost; the events that precipitated economic transition with special attention to oligarchs, globalization, and commodification; and postsocialism as a historiographical suggestion to everything after "the transition." Chapter 3 engages the classical anthropological themes of cultural rationalities, meaning, and significance, which in this case is "Loss, Memory, and Religion." It opens up with a discussion of Serguei Oushakine's treatment of loss as a key conceptual term, moving to nostalgia, the materiality of memory in postsocialist monuments, and the activities of the groups Memorial and Pamiat'. The ethnographic close-up discusses the demand for Stalin-related memorabilia. A section on religion compliments Douglas Rogers's discussion of Old Believers' religious practice with Jarret Zigon's investigation of the role of the Russian Orthodox Church in constructing moral personhood in the rehabilitation of drug users. All these are compared with the gendered use of ritual among Buddhists in Russia, based on the work of Anya Bernstein. Other chapters also closely reflect their titles and offer discussions, respectively, on "Identity, Nationalism, and Community-Making," "Political Culture, Democracy, and Protest," "Gender, Sex, and Desire," "Media and Art," and a discussion of the Russian diaspora in Germany in the final chapter, "Russia beyond Russia."

The text therefore covers a lot of ground in the style of an annotated bibliography, with key terms outlined in bold. It should be a convenient tool for anyone teach- 
ing a course on ethnography of Russia, socialism and postsocialism, introductory anthropology, or political and public anthropology. The discussion questions and "further reading suggestions" provided at the end of each chapter, and sometimes in the text itself, are further useful pedagogical enhancements. One inconvenience is the confusing construction of bibliographies. It is impossible to know at a glance whether the "Insights" contain a reference to a particular source because "further reading suggestions" do not appear in the final bibliography or in the index (for instance, p. 22 contains a reference to Luehrmann 2011, which is then cited in the further reading list, but not in the bibliography nor the index). The author explains the controversy around the fact that anthropology of Russia is dominated by anthropologists coming from Western Europe and North America (p. 3), yet the bibliographies lean heavily to Western authors at the expense of non-Western ones, which runs counter to the book's decolonizing ambitions. Transliteration is sloppy at times: for instance, the political group Память loses its soft sign at the end (Pamiat), while блат, an "informal exchange and barter system" (p. 101), becomes very close to the most popular Russian profanity by acquiring one (blat').

Perhaps the greatest challenge of a text such as this is that both the brevity and narrowness of focus make it problematic for precisely its intended broader usenamely, to introduce Russia to non-Russian students in an open-minded, contextual, and unbiased anthropological way. On the one hand, the book's political and contemporary focus provides a shift away from views of Russia that are centered excessively on the agonies of its history and the glory of its literature. On the other hand, the book itself is not free of bias. For example, covering of what would be the classical anthropological theme of local rationality in terms of "loss and memory" without complementing it with, for instance, a "topography of happiness" (as in the collection of essays edited by Nikolai Ssorin-Chaikov [2013]) reinforces, rather than undermines, pathologizing views of people in Russia. Some deeper engagement with leisure and pleasure themes in works such as Dacha Idylls (Caldwell 2010) would provide a welcome balance to the memory, loss, protests, and complaints. In the "Religion" section of Chapter 3, the analysis is centered on political implications and leaves little space for the ways in which ambient, everyday, or familial religiosity operates in contemporary Russia. Perhaps, asking for balance and context may be seen as unjustified considering the demand for increasingly short formats on the part of most publishers. There is also a disclaimer (p. 5) that the book was a reluctant yet needed answer to the students' demand for a short introductory text. These still cannot justify the rather simplistic treatment of the chosen focus. The book claims to ask (p. 48) - and yet does not ask-what constitutes "the political" either locally or in a broader anthropological sense; instead, politics appears to be predefined as a fight between progressive and conservative forces, represented by groups of people-and predominantly by political activists. As a result, this allegedly anthropological book strangely dehumanizes the people of Russia, who do not seem to have lives, loves, or struggles beyond coping with loss or fighting for what the author sees as political alternatives. 
Most anthropologists are deeply critical of viewing postsocialist change in terms of "transitioning" away from a single-party system and a command economy to some new, presumably more liberal, political and economic order. The book contains a brief discussion of this critique in the beginning ( $p .15)$, and yet, on the whole, it continues to emphasize the "democracy" and "change" of the postsocialist era at the expense of potential continuities. Some great summaries of sophisticated theories are undermined by unfortunate choices of words that betray political partisanship. For instance, an excellent recap of Alexei Yurchak's complex and sophisticated argument about the work of Soviet ideology is concluded with a statement that Soviet ideological pronouncements did not have "any real meaning being attached to them" (p. 10). Similarly, the juxtaposition between two groups of social activists, Memorial and Pamiat', is presented as a contrast between "memory" and "myth." Indeed, the conceptualization of memories or ideas as "mythical" appears to run throughout the book (e.g., in the section "Home/Myth as Disappointment," p. 96). While in some cases the use of the "myth" framework may be justified, in the necessarily brief rendition of the book the "mythical" amounts to simply "fake"- - troubling development for a book that is supposed to present both anthropology and Russia to a more general public. Is the idea that all mythic orders are a form of false consciousness? Other word choices are simply unfortunate. I will provide two examples. Firstly, perestroika is described as an "awakening," Orientalizing the Soviet Union in the spirit of a "sleeping giant," as presaged so well in the work of Johannes Fabian ([1983] 2014). At the very least, the fact that many Russians today would characterize this "awakening" more in terms like "brainwashing into capitalism" should have precluded using this word in a chapter title and without quotation marks. Secondly, the political system of the Soviet Union is redeemed as "more open and porous system than many negative assessments would have us to believe" (p. 10; emphasis added). A student of anthropology should also be asking if the locals think that "porousness" is a positive quality in a political system.

As a whole, the book appears to send the message of "give poor Russia a chance to become a good liberal-democratic country." In this message, anthropology is given the role of a truth-seeking discipline that has tools to provide empirical, grassroots evidence that people of Russia are not culturally and politically hopeless but have the potential to become "good." The book ultimately reminds us that colonial mindsets can infuse even the best of intentions - those of policy makers and anthropologists alike.

\section{REFERENCES}

Caldwell, Melissa L. 2010. Dacha Idylls: Living Organically in Russia's Countryside. Berkeley: University of California Press.

Fabian, Johannes. [1983] 2014. Time and the Other: How Anthropology Makes Its Object. New York: Columbia University Press.

Ssorin-Chaikov, Nikolai. 2013. Topografiia schast'ia: Etnograficheskie karty moderna. Moscow: NLO. 